\title{
十津川流域で発生した土砂災害の検証及び 避難意思決定支援の在り方 \\ THE STUDY ON VALIDATION OF SEDIMENT DISASTER AT THE TOTSUKAWA RIVER BASIN AND METHOD OF EVACUATION DECISION- MAKING SUPPORT
}

\author{
戸田淳治 1 ・田中茂信 2 -田中賢治 3 ・浜口俊雄 4 \\ Junji TODA, Shigenobu TANAKA, Kenji TANAKA and Toshio HAMAGUCHI \\ 1学生会員 京都大学大学院 工学研究科都市社会工学専攻（干 615-8530 京都市西京区京都大学桂） \\ 2正会員 博（工） 京都大学 防災研究所 教授（干611-0011 宇治市五ヶ庄） \\ 3 正会員 博 (工) 京都大学 防災研究所 准教授（干611-0011 宇治市五ヶ庄） \\ 4正会員 博 (農) 京都大学 防災研究所 助教（广611-0011 宇治市五ヶ庄）
}

\begin{abstract}
To reduce victims for a disaster that is due to rainfall, we are advancing the development of the system, which support evacuation decision-making for the persons in charge of the disaster prevention and the concerned residents. The objective of our research is that we specify the direction of evacuation decision-making, which is shown by the areal unit. For the uncertainty of the calculation accuracy, we start with the reproduction calculation on the 2011 Totsukawa event.

To implement the above-mentioned objective, the risk index of the sediment disaster is estimated. The accuracy of the calculation result is validated by collapse record and others.
\end{abstract}

Key Words : sediment disaster, risk index, tank model, evacuation decision-making support

\section{1. はじめに}

集中豪雨などが原因で我が国では毎年のように風水害 が発生し，その犠牲となる方々が後を絶たない. その内 訳を見ると土砂災害による犠牲者数が最も多いという現 状がある，そのため砂防ダム等の整備(ハード対策) 及び 防災システムの高度化(ソフト対策) で土砂災害の被害を 少しでも減らす取り組みが重要である. 人命を守る観点 から土砂災害が発生する危険が迫っている時の避難行動 がとりわけ重要であり, その意思決定を支援するため避 難情報を必要とする方々への迅速且つ正確な情報伝達が 不可欠である．ただ現状では防災システムの予測精度等 の問題により，個々の場所で個々のイベントに対し避難 が必要な危険な状況なのか，あるいはいつどこへ避難す ればよいのかが明確とはなっていない. 本研究では避難 の必要性の有無, そのタイミング, 避難場所(水平避難 または垂直避難)を市町村よりも狭い地区単位で明示す ることで防災担当者や住民の避難に対する意思決定の支 援を目標としている。しかしながら計算精度の不確実性 の問題があるため, 過去のイベントの再現計算を行って
その精度を検証することから始める．取り扱う事例は土 砂災害などにより多くの人命が奪われた2011年9月の紀 伊半島豪雨災害である.

\section{2. 本研究の概要}

\section{（1）避難意思決定支援システム}

現在我々は前章で述べた避難の意思決定を支援するた めのシステムを開発中である。「過去事例の再現計算」 を選択すると土砂災害に関する危険度の時空間分布が出 力される，それと同時に地区単位で避難に関する指針を 防災担当者及び住民向けに出力し，平常時に擬似体験す ることで今後起こり得るイベントに備えていただく.

(2) 入出カデータ

本研究では雨量データを入力とし，次節で説明する土 砂災害モデルにより土壌雨量指数及び土砂災害警戒レベ ル值を算定する. 土壌雨量指数はYasuo Ishihara, Shigeki Kobatake ${ }^{1)}$ のタンクモデルを採用し，土砂災害警戒レベ ル值は算定された土壤雨量指数と60分間積算雨量, 土砂 
災害警戒基準線，大雨警報及び注意報基準值から求める.

\section{(3) 土砂災害モデル}

図-1に前節で述べたタンクモデルの概念図，表-1にモ デルパラメータを示す，モデル基礎式は参考文献をを参 照されたい

気象庁では全国一律のパラメータを採用し (表-1の

「Tsukigase」で花崗岩に対応)，5kmメッシュごとに土壌 雨量指数を算定している. 本研究では従来の方法(気象 庁と同様)に加えて表-1に示された地質ごとの異なるパ ラメータを採用する方法も試した。また空間解像度は $1 \mathrm{~km}$ であ.

以下では従来の方法(土壃雨量指数を全メッシュで一 様な地質情報から算定)をケースA，本研究で試みた方法 (土壤雨量指数にメッシュ毎で異なる地質情報を反映)を ケースBと呼ぶことにする.
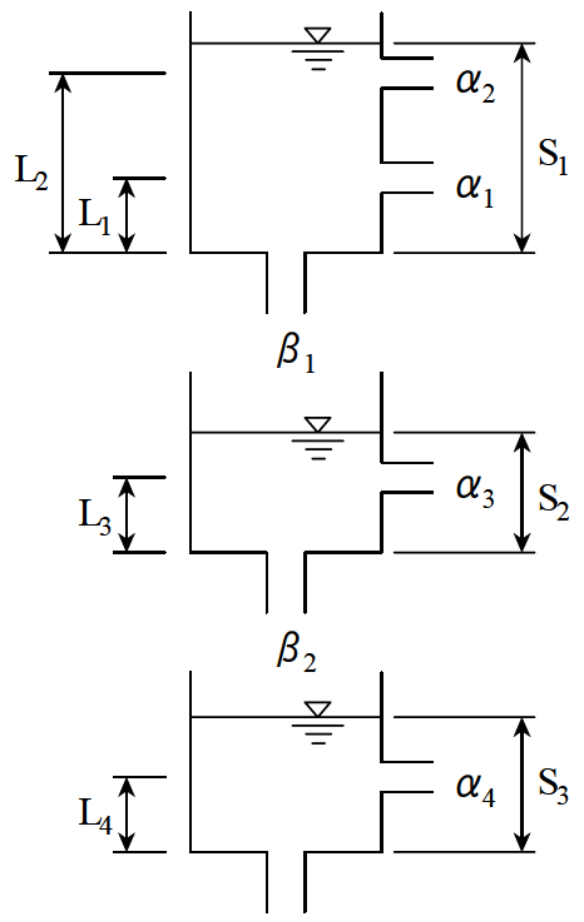

$\beta_{3}$

\section{(4) 危険度指標}

土砂災害を発生させる原因として誘因と素因がある。 誘因としては雨量及び土壤雨量指数，素因としては斜面 形状や地質などが挙げられる. 本研究では両者を考慮し た新たな危険度の指標を $1 \mathrm{~km}$ メッシュの解像度で算定す る.

\section{(5) 既存の研究との比較}

(3)節で述べたような，タンクモデルに対して地質ごと に別々のパラメータを割り当てる手法は気象庁において 田中ら ${ }^{3)}$ が行っている．ただ気象庁では当該手法を流域 雨量指数の算定に関し適用しており，土畩雨量指数につ いては(3)節で述べた通りである.

また，(4)節で述べたような複数の危険因子を考慮して 土砂災害の危険度を見積もる研究は北園ら ${ }^{4,5)}$ が行ってい る. 本研究では起伏量や最大傾斜角などの斜面形状だけ でなく雨量及び土壤雨量指数を危険因子に含め，さらに 気象状況を加味して最大傾斜方向の危険度レベル值を決 定すること等で既往研究との差別化を図った.

\section{3. 計算方法}

\section{(1) 土袞雨量指数 (ケースBで算定)}

計算対象地域は2011年9月に発生した豪雨災害により 大きな被害を受けた奈良県十津川村である。まず図-2に 十津川村の地質分布図を示す．紫色で囲まれた領域が十 津川村の範囲である. 黄色枠(左)は実際に崩壊した場所 を示しており，黄色枠(右)は拡大図である。このメッ シュに関しては深成岩のカテゴリが面積最大であり，表 -1の「Tsukigase」のパラメータを使用する.

他のメッシュについても地質に応じて表-1のいずれか のパラメータを割り当てる. 具体的には第三紀堆積岩の メッシュは「Kiyohorobashi」のパラメータ, 中世代堆積 岩のメッシュは「Kiyohorobashi」(年代が第三紀に近い ため), 年代が第四紀更新世に近い火山岩のメッシュは

「Kohira」のパラメータを割り当てた.

図-1 タンクモデル概念図 (参考文献)より引用)

表-1 タンクモデルパラメータ

\begin{tabular}{|c||l|l|l|l|l|l|l|l|l|l|l|}
\hline name & $\begin{array}{c}\mathrm{L}_{1} \\
(\mathrm{~mm})\end{array}$ & $\begin{array}{c}\mathrm{L}_{2} \\
(\mathrm{~mm})\end{array}$ & $\begin{array}{c}\mathrm{L}_{3} \\
(\mathrm{~mm})\end{array}$ & $\begin{array}{c}\mathrm{L}_{4} \\
(\mathrm{~mm})\end{array}$ & $\begin{array}{c}\beta_{1} \\
(1 / \mathrm{hr})\end{array}$ & $\begin{array}{c}\beta_{2} \\
(1 / \mathrm{hr})\end{array}$ & $\begin{array}{c}\beta_{3} \\
(1 / \mathrm{hr})\end{array}$ & $\begin{array}{c}\alpha_{1} \\
(1 / \mathrm{hr})\end{array}$ & $\begin{array}{c}\alpha_{2} \\
(1 / \mathrm{hr})\end{array}$ & $\begin{array}{c}\alpha_{3} \\
(1 / \mathrm{hr})\end{array}$ & $\begin{array}{c}\alpha_{4} \\
(1 / \mathrm{hr})\end{array}$ \\
\hline \hline Kohira & 40 & 75 & 15 & 15 & 0.12 & 0.08 & 0.01 & 0.10 & 0.15 & 0.05 & 0.01 \\
\hline Minamihatajiki & 30 & 60 & 15 & 15 & 0.12 & 0.08 & 0.01 & 0.10 & 0.15 & 0.05 & 0.01 \\
\hline Tsukigase & 15 & 60 & 15 & 15 & 0.12 & 0.05 & 0.01 & 0.10 & 0.15 & 0.05 & 0.01 \\
\hline Mino & 30 & 75 & 5 & 15 & 0.12 & 0.04 & 0.01 & 0.10 & 0.15 & 0.05 & 0.01 \\
\hline Kiyohorobashi & 15 & 40 & 5 & 15 & 0.12 & 0.04 & 0.01 & 0.10 & 0.15 & 0.05 & 0.01 \\
\hline
\end{tabular}




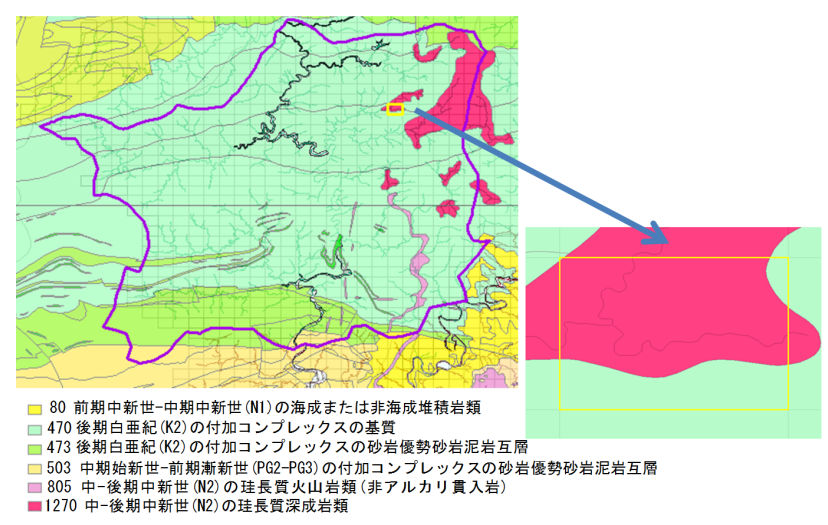

図-2 十津川村の地質分布図

\section{(2) 危険度指標}

まず北園ら ${ }^{4), 5)}$ が行った方法にならい，土砂災害の危険 因子ごとにカテゴリ別の危険度レベル值を設定する．本 研究で用いた危険因子には以下のものがある.

\section{a) 雨量及び土壤雨量指数}

2章(2)節で述べたようにこれらは土砂災害の警戒レベ ル值の算定に用いられる。その空間解像度は土壌雨量指 数と同様に $1 \mathrm{~km}$ である.

また，入力データの土砂災害警戒基準線は土壌雨量指 数への地質情報の反映の有無にかかわらず一律の值を使 用した。

本研究では2013年までの過去10年程度の土壌雨量指数 履歴順位が最上位で，かつ2位より $200 \mathrm{~mm}$ 以上大きい格 子点の警戒レベルを「1.0」とした．また実況で土砂災 害警戒情報の基準超過を「0.8」，予想で土砂災害警戒 情報の基準超過を「0.6」，大雨警報の土壌雨量指数基

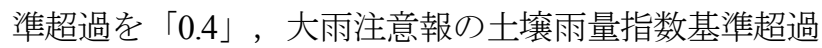
を「 $0.2 」$, 大雨注意報の土壌雨量指数基準未満を

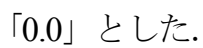

\section{b) 起伏量}

国土数值情報の標高・傾斜度5次メッシュデータ(G04-

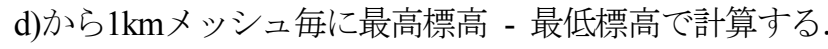
$500 \mathrm{~m}$ 以上を「1.0」，400m以上 $500 \mathrm{~m}$ 未満を「0.75」， $300 \mathrm{~m}$ 以上 $400 \mathrm{~m}$ 未満を「0.5」，200m以上 $300 \mathrm{~m}$ 未満を $\lceil 0.25 」, 200 \mathrm{~m}$ 末満を「0.0」とした.

\section{c) 最大傾斜角}

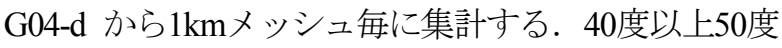
未満を「1.0」，30度以上40度未満を「0.75」，30度未満 を「0.5」，50度以上を「0.25」とした。

\section{d）最大傾斜方向}

G04-d から $1 \mathrm{~km}$ メシュュ毎の最大傾斜角に対応するカ テゴリを抽出する. 当時の気象状況から南東または南を $\lceil 1.0 」 ，$ 東または南西を「0.75」，北東または西を $「 0.5 」 ，$ 北または北西を「0.25」とした.

\section{e) 横断形状}

北園ら ${ }^{4)}$ の手法と同様に算定し，凹を「1.0」，凸及び 平面を「0.5」とした.

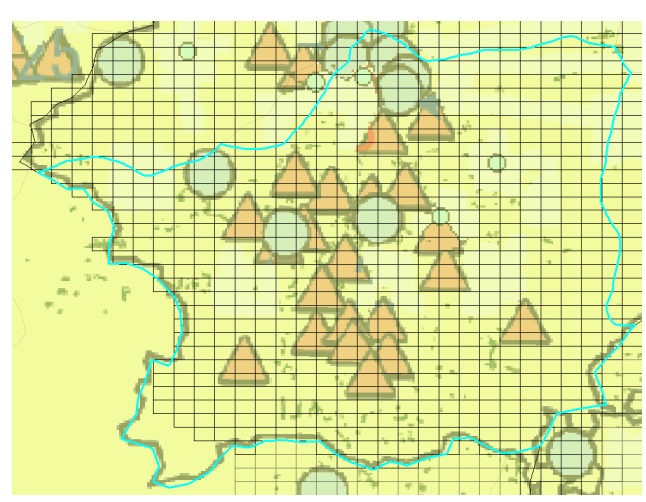

図-3 十津川村における過去の崩壊実績

\section{f）地質}

土壌雨量指数をケースAで算出した場合は単独で危険 因子に含める. 火山岩系及び深成岩を「1.0」，第四紀 を「0.8」，第三紀を「0.6」，中生代を「0.4」，変成岩 及び古生代を「0.2」とした。

\section{g）土地利用及び植生}

広葉樹林を「1.0」，針葉樹林・田・畑を「0.5」とした。

\section{h）過去の崩壊実績}

図-3は十津川村周辺における過去の斜面崩壊を示して いる. 丸印は2011年崩壊実績, 三角印は過去(1889年と 1953年)の崩壊実績である.1889年または1953年の崩壊 実績が存在するメッシュを「1.0」，存在しないメッシュ を「0.0」とした.

\section{4. 算定結果及び考察}

(1) 危険度指標 (ケースAで算定)

\section{a) 解析雨量データ}

図-4はタンクモデルで全国一律のパラメータを使用し， 3章(2)節で述べた手法で土砂災害の警戒レベル值を算定 した結果である．モデルにおけるタイムステップは10分 であるが，警戒レベル值の判定は60分毎に行った.これ は雨量及び土㙵雨量指数のみ考慮した結果を示している.

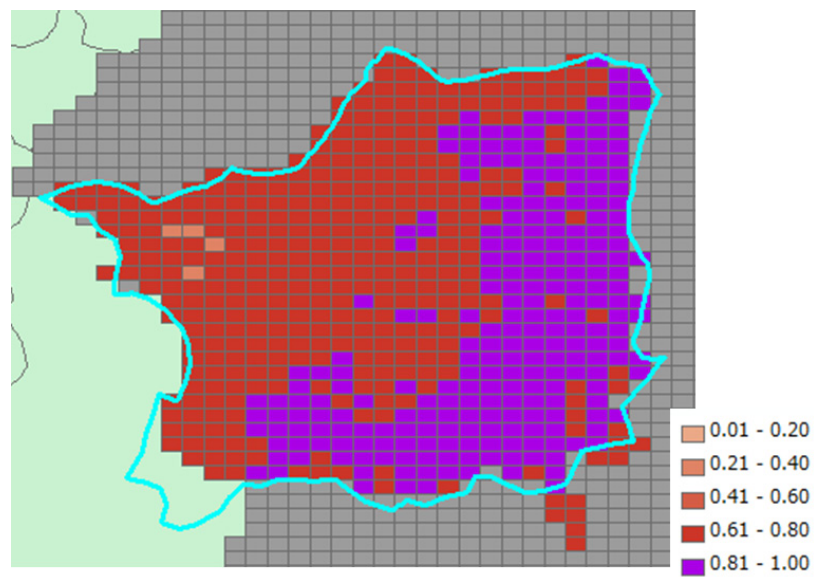

図-4 危険度指標 : 2011年紀伊半島豪雨災害 雨量及び土壤雨量指数のみ考慮, 解析雨量使用 
表-2 分割表 : 雨量及び土壤雨量指数のみ考慮

\begin{tabular}{||c|r|r|r||}
\hline & \multicolumn{1}{|c|}{1} & \multicolumn{1}{|c|}{0} & \multicolumn{1}{|c|}{ 合計 } \\
\hline yes & 11 & 55 & 66 \\
\hline no & 237 & 309 & 546 \\
\hline 合計 & 248 & 364 & 612 \\
\hline
\end{tabular}

表-3 各危険因子の的中率によるランク付け : ケースA

\begin{tabular}{||c|c|c||}
\hline アイテム & 的中率 & 順位 \\
\hline 雨量·土䞿雨量指数 & 0.523 & 6 \\
\hline 起伏量 & 0.631 & 4 \\
\hline 最大傾斜角 & 0.240 & 8 \\
\hline 最大傾斜方向 & 0.590 & 5 \\
\hline 横断形状 & 0.492 & 7 \\
\hline 地質 & 0.851 & 1 \\
\hline 土地利用·植生 & 0.761 & 3 \\
\hline 過去の崩壕実綪 & 0.768 & 2 \\
\hline
\end{tabular}

なお，入力雨量データは空間解像度が $1 \mathrm{~km} の$ 解析雨量で あり，水色枠で示した十津川村のみを算定対象としてい る.

次に表-2で示した分割表により算定結果の検証を行う。 この場合危険度レベル值が「1.0」(カテゴリ1)で実際に 斜面崩壊があった(yes)メッシュが11個，危険度レベル值 が「1.0」以外(カテゴリ0)で斜面崩壊があったメッシュ が55個, カテゴリ 1 と非崩壊(no)の組み合わせが237個, カテゴリ0と非崩壊の組み合わせが309個である.

これより的中率を算出し，他も同様に行い表-3のよう に各危険因子をランク付けする。順位が高い(低い)ほど

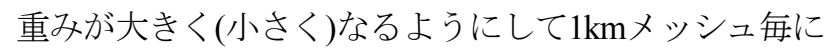
各危険因子の危険度レベル值（3章(2)節で説明）を加重 平均して危険度指標とする，表-4及び図-5はその結果で ある．危険度指標が「0.7」を超えるメッシュを最大力 テゴリ(紫色)としている.

図-6の雨量及び土壌雨量指数のみ考慮した結果(ver.1) と危険因子を全て考慮した結果(ver.2)を比較すると，非 崩壊的中メッシュ数が大幅に増加したため的中率が大幅 に増加, 見逃し率は変化がないものの空振り率は大幅に 改善した.

なお，的中率，見逃し率，空振り率は分割表から次式 で計算される(表-2の場合).

$$
\begin{aligned}
\text { 的中率 } & =(11+309) / 612=0.523 \\
\text { 見逃し率 } & =55 / 612=0.090 \\
\text { 空振り率 } & =237 / 612=0.387
\end{aligned}
$$

加えて, 危険度最大カテゴリの閾值は次のような理由 で「0.7」を採択した.

・危険度指標が「0.6」の場合，「0.7」と比べて空振り率 が大きい(図-6における空振り率の改善度合いが小さい) . ・危険度指標が「0.8」の場合，「0.7」と比べて的中率は 高いものの崩壊的中メッシュ数が2個と少ない.
表-4 分割表 : 全ての危険因子を考慮

\begin{tabular}{||r|r|r|r|}
\hline & 1 & \multicolumn{1}{|c|}{0} & \multicolumn{1}{|c|}{ 合計 } \\
\hline yes & 12 & 54 & 66 \\
\hline no & 56 & 490 & 546 \\
\hline 合計 & 68 & 544 & 612 \\
\hline
\end{tabular}

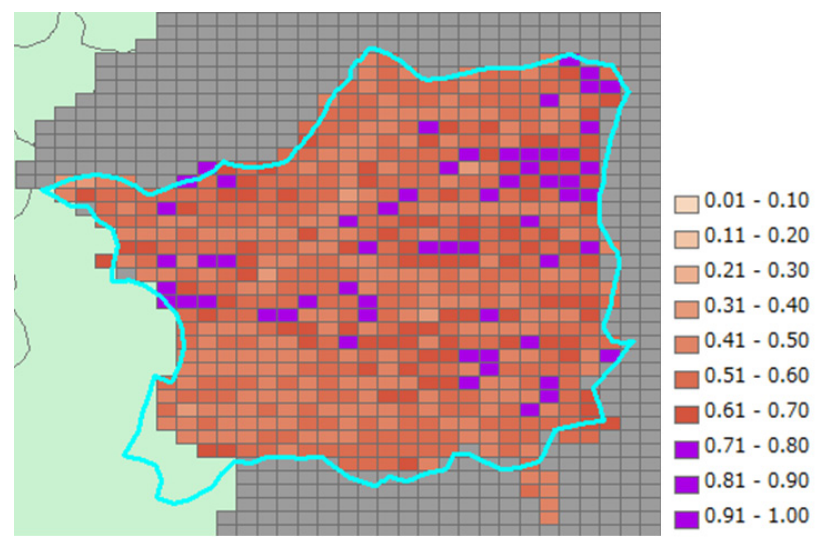

図-5 危険度指標 : 2011年紀伊半島豪雨災害 全ての危険因子を考慮, 解析雨量使用

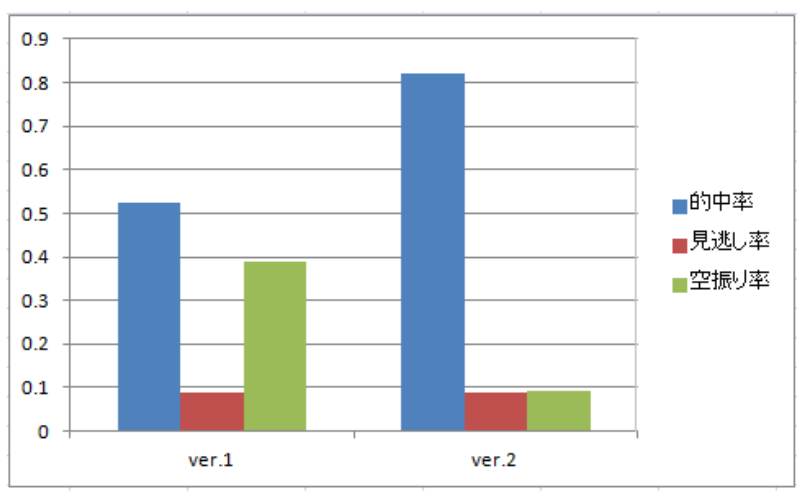

図-6 危険度評価の検証結果 (ケースA) 雨量及び土壤雨量指数のみ考慮 vs. 全ての危険因子を考慮

\section{b）メソアンサンブル雨量データ}

本雨量データは空間解像度が $2 \mathrm{~km}$, メンバ数は 11 であ る. 2011年9月1日から2011年9月4日まで毎日3時[JST]を 初期時刻とする30時間予報をつなぎ合わせて9月1日9時 [JST]から9月5日9時[JST]までの予報データとしている.

各予報の初期時刻から6時間後まではスピンアップ期間 として除いている。なお本データは文部科学省の 「HPCI戦略プログラム」の中での実証実験結果であり， 将来的には現業で使用予定となっている.

十津川村に含まれる全メッシュに対して上記予報期間 の積算雨量を合計してみると，図-11で示した全メンバ の中でその積算雨量の実測との差が最も小さいメンバは 「p03」である. 図-7はケースAで危険度指標を算定し た結果である. 図-5と比べると最大カテゴリ(紫色)の分 布はあまり変化がなく, 分割表で的中率等の検証を行っ てもほとんど差がなかった。つまり「p03」に関しては 精度良く予報できていることになる。 


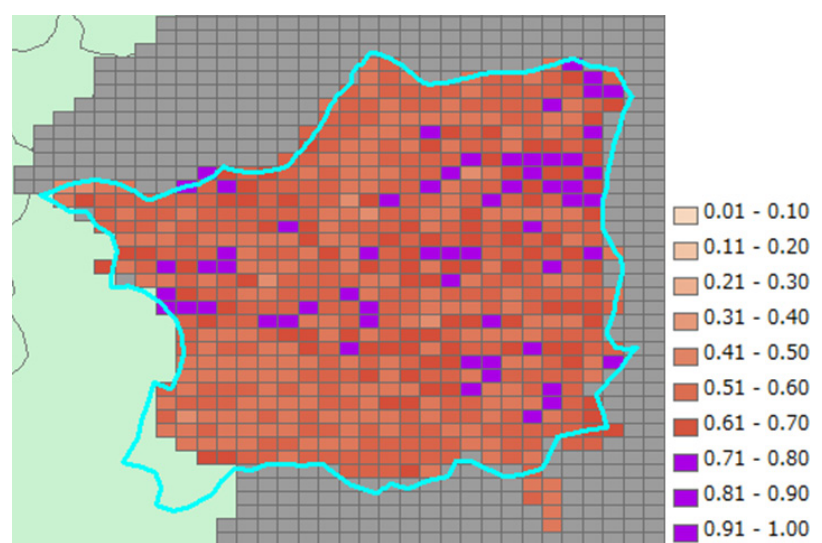

図-7 危険度指標 : 2011年紀伊半島豪雨災害 全ての危険因子を考慮，メソアンサンブル雨量使用 (p03)

\section{(2) 危険度指標 (ケースBで算定)}

入力雨量データに解析雨量を用いタンクモデルで地質 ごとの異なるパラメータを使用し，(1)節と同様に分割表 を用いて危険因子毎に的中率を算出した。 そして表-5の ように各危険因子を的中率により順位付けして危険度指 標を求めた．表-3と表-5 を比べると，表-3で最上位の 地質を雨量及び土壌雨量指数に反映させることによりそ の順位は6位から3位に上昇した(図-8におけるver.1の的 中率に対応). ただ図-8のように全ての危険因子を考慮 した場合(ver.2)とで的中率，見逃し率，空振り率はあま り変化がなかった.

表-5 各危険因子の的中率によるランク付け : ケースB

\begin{tabular}{||c|c|c||}
\hline \hline アイテム & 的中率 & 順位 \\
\hline 雨量·土䞿雨量指数 & 0.755 & 3 \\
\hline 起伏量 & 0.631 & 4 \\
\hline 最大傾斜角 & 0.240 & 7 \\
\hline 最大傾斜方向 & 0.592 & 5 \\
\hline 横断形状 & 0.492 & 6 \\
\hline 土地利用·植生 & 0.761 & 2 \\
\hline 過去の崩壊実綪 & 0.766 & 1 \\
\hline \hline
\end{tabular}

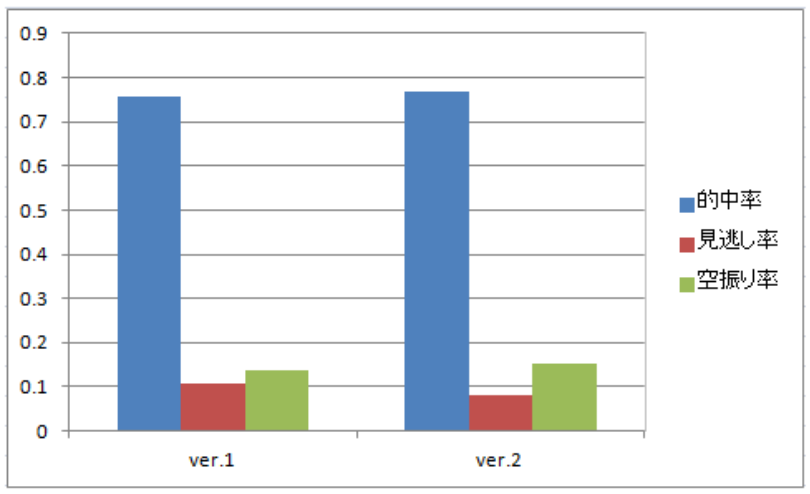

図-8 危険度評価の検証結果 (ケースB)

雨量及び土壤雨量指数のみ考慮 vs. 全ての危険因子を考慮

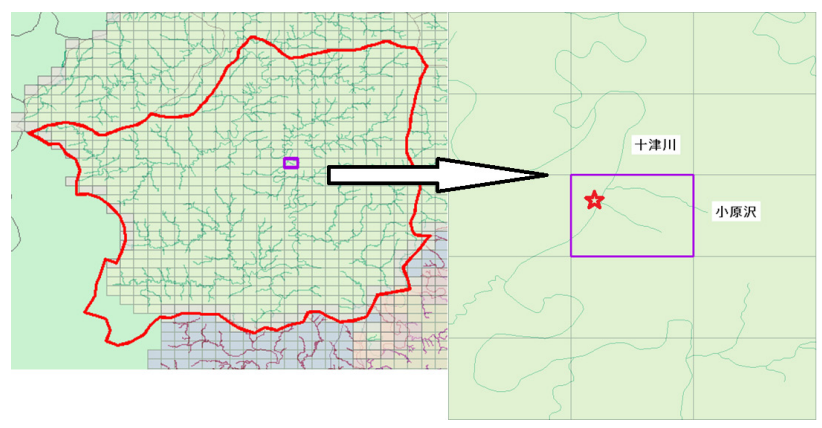

図-9 十津川村野尻地区位置

\section{危険度指標表示}

risk_index

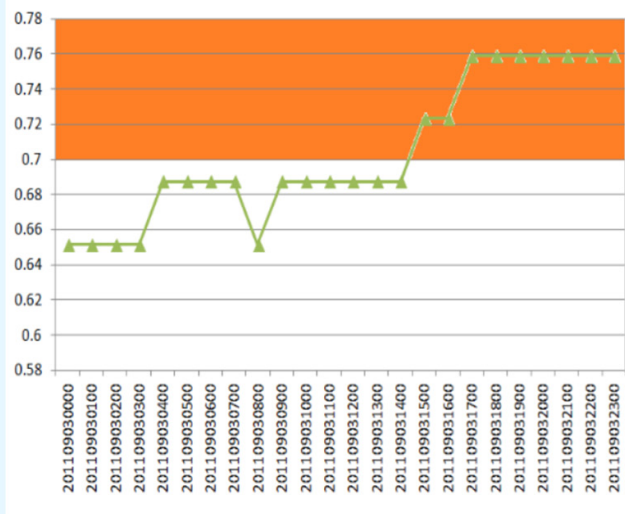

遅くとも9月3日15時までに 避難所への水平避難を開始して下さい

図-10 危険度指標時系列データ及び避難の最適タイミング表示 十津川村野尻地区 : 9月3日，1時間ごとの推移

\section{(3) 避難意思決定支援}

図-9における紫色枠は十津川村野尻地区の代表メッ シュを示している．星印は土砂災害の被災地点である村 営住宅である。参考文献6),7),8 にあるように野尻地区では 9月3日18時30分過ぎに深層崩壊が発生し，土石流が小原 沢から十津川に流入して川沿いの村営住宅が被災し，10 名近くの犠牲者を出す大きな災害となった.

また，図-10は9月3日における十津川村野尻地区の危 険度指標時系列データである. 入力雨量データは解析雨

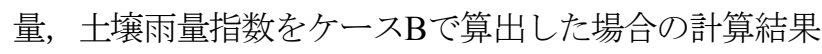
である．橙色部分は危険度最大カテゴリ (0.7以上)を表し ており，表示結果のような指針を示すことができれば犠 牲者の減少につながる可能性がある.

なお，土砂災害危険度を評価するメッシュサイズとし て1kmメッシュを採用した理由であるが，十津川村野尻 地区で発生した土砂災害全体の水平規模が $1 \mathrm{~km}$ 程度(深層 崩壊部分から土石流の流下部分を経て被災地点の村営住 宅まで)であり，他の地区でも深層崩壊の水平規模が数 $100 \mathrm{~m}$ 程度で，土砂災害警戒区域の広がりも考慮すると 


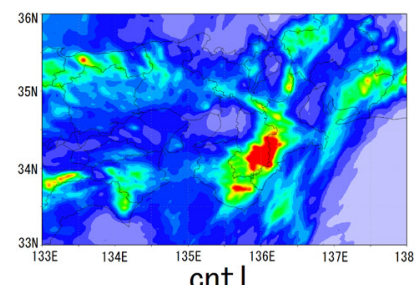

cntl
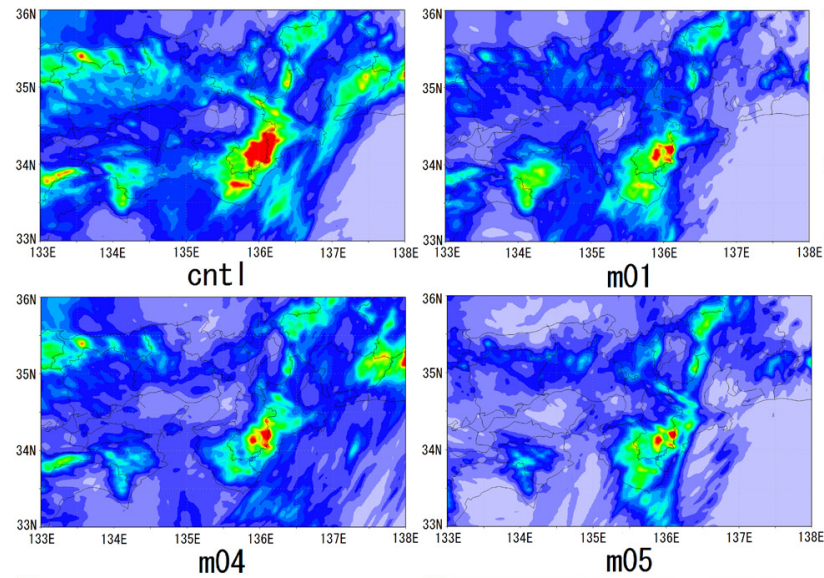

m01
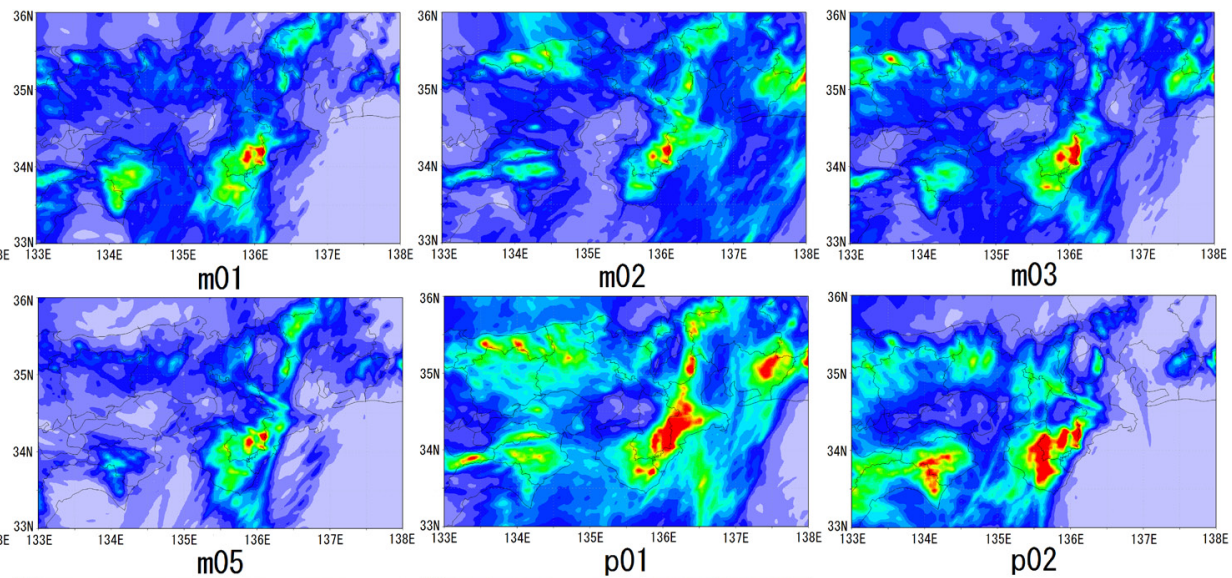

$\mathrm{m} 02$

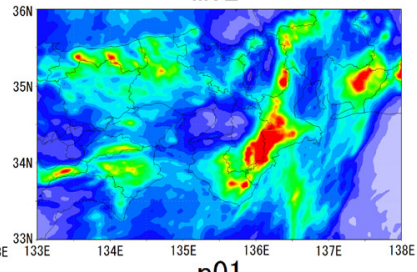

$\mathrm{p} 01$
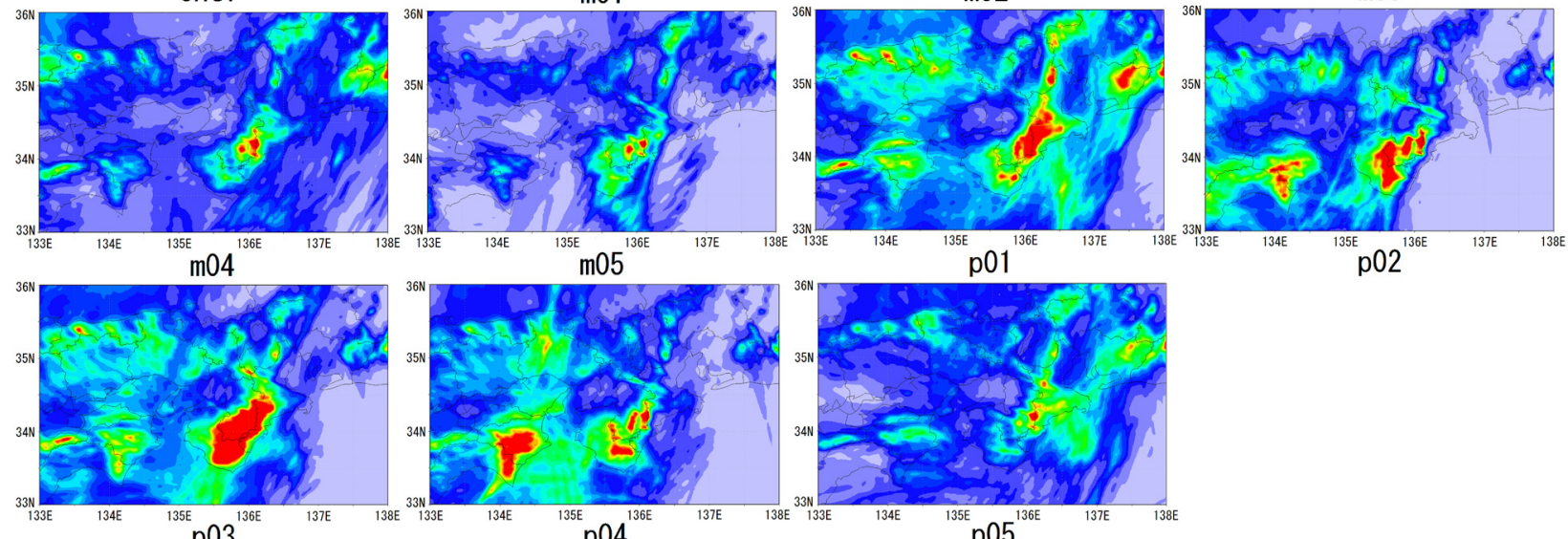

p05

0501001502002503003504004505005506006507007508008509009501000

図-11 メソアンサンブル予測によるメンバ毎の積算雨量 : 2011年9月1日9時[JST]～2011年9月5日9時[JST]，単位[mm]

$1 \mathrm{~km}$ メシュが妥当であると考える.

\section{5. 結論}

本研究で得られた知見をまとめると以下のようにな る.

・本研究で用いた手法による土砂災害危険度見積もりに 関し，それを2011年の紀伊半島での深層崩壊事例に 適用しても的中率や空振り率の改善が見られ，ある 程度は有効であった。

- 土壌雨量指数に地質情報を反映させることで土壌雨量 指数そのものの的中率は向上したが，全ての危険因 子を考慮した場合との比較では変化がなかった。

・ 1 章で述べた避難に関する指針を地区単位で明示する という目標に対し，2011年紀伊半島豪雨災害の再現 計算において本研究で提案した危険度指標を用いる ことにより特定の地区に対する避難指針を土砂災害 発生の数時間前に示すことができ，これを今後発生 し得る他のイベントでも適用できれば犠牲者の減少 につながる可能性が示された.

今後の最も重要な課題はシステムのリアルタイムで の運用である. 今回は過去事例の再現計算でアンサンブ ル予報を適用したため精度の高い予報とそうでないもの を切り分けることができたが，予測の段階でそれをどの ように切り分けシステム化するのかが問題である.

また, 土壌雨量指数に地質情報を反映させることの 有効性の有無を他の事例でも検証寸る必要がある. 本研
究で用いた手法が他の土砂災害事例にも適用できるのか データの蓄積が肝要である.

とりわけ重要な点は避難意思決定の支援をリアルタイ ムでいかにして行うかである．避難を始めとする情報を いつどのような手段で提供すれば被害の軽減につながる のか今後も十分に検討を続けなければならない.

\section{参考文献}

1) Yasuo Ishihara, Shigeki Kobatake. Runoff Model for Flood Forecasting, Bull.D.P.R.I. Kyoto University, 29(1), pp.27-43, 1979.

2）国土交通省河川局砂防部，気象庁予報部，国土交通省国土 技術政策総合研究所：国土交通省河川局砂防部と気象庁予 報部の連携による土砂災害警戒避難基準雨量の設定手法

(案)，別紙資料 $1 ， 2005$

3) 田中信行, 太田玩磨, 牧原康隆 : 流域雨量指数による洪水 警報・注意報の改善，測候時報，75.2，pp.35-69， 2008

4) 北園芳人，仲宗根典子，寺園忠彦：地盤情報データベース の作成と斜面崩壊予測への応用, 自然災害科学, 20(1), pp.75-87, 2001

5) 北園芳人，井上敦裕 : 斜面崩壊の素因に注目した斜面の危 険度評価，第 4 回土砂災害に関するシンポジウム論文集, 2008

6) 土木学会平成 23 年台風 12 号土砂災害現地調査団 : 土木学会 平成23年台風12号土砂災害調查報告書，2011

7) 土木学会地盤工学委員会斜面工学研究小委員会現地調查 団: 平成23年台風12号土砂災害第2回調査報告書, 2012

8) 稲泉連：ドキュメント豪雨災害 そのとき人は何を見るか, 岩波新書, 2014

(2014. 9. 30受付) 